\title{
Photochemical Redox Decomposition of $\mu$-Cyano-pentacyanoruthenium (II)pentaamminecobalt(III) Ion
}

\author{
Arnd Vogler and Horst Kunkely \\ Fachbereich Chemie, Universität Regensburg, 84 Regensburg, Germany
}

Absorptionsspektren, sichtbar und ultraviolett / Komplexverbindungen / Photochemie

In the complex ion $\left[\left(\mathrm{NH}_{3}\right)_{5} \mathrm{Co}(\mathrm{III}) \mathrm{NCRu}(\mathrm{II})(\mathrm{CN})_{5}\right]^{-}$both metals are linked by a cyanide bridge. The electronic spectrum of this compound exhibits a new absorption band which does not occur in the spectra of the two isolated $\mathrm{Co}(\mathrm{III})$ and $\mathrm{Ru}(\mathrm{II})$ complexes which constitute the binuclear complex. This new band is assigned to an intervalence transfer (IT) transition from $\mathrm{Ru}(\mathrm{II})$ to $\mathrm{Co}$ (III). Upon irradiation into this band the aqueous binuclear complex underwent a redox reaction under formation of $\mathrm{Ru}(\mathrm{CN})_{6}^{3-}$ and $\mathrm{Co}^{2+}$ with a quantum yield $\phi=0.46$.

The mechanism of this photochemical reaction and its relationship to similar thermal redox reactions is discussed.

Im Komplexion $\left[\left(\mathrm{NH}_{3}\right)_{5} \mathrm{Co}(\mathrm{III}) \mathrm{NCRu}(\mathrm{II})(\mathrm{CN})_{5}\right]^{-}$sind beide Metalle durch eine Cyanidbrücke verbunden. Das Elektronenspektrum dieser Verbindung enthält eine neue Absorptionsbande, die nicht in den Spektren der beiden isolierten Co(III)- und Ru(II)-Komplexe, die den zweikernigen Komplex bilden, auftritt. Diese neue Bande wird einem intervalence transfer (IT)-Übergang vom Ru(II) zum Co(III) zugeordnet. Der in Wasser gelöste Komplex unterliegt einer Redoxreaktion unter Bildung von $\mathrm{Ru}(\mathrm{CN})_{6}^{3-}$ und $\mathrm{Co}^{2+}$ mit der Quantenausbeute $\phi=0,46$, wenn Licht in diese IT-Bande eingestrahlt wird. Der Mechanismus dieser photochemischen Reaktion und ähnlicher thermischer Redoxreaktionen wird diskutiert.

\section{Introduction}

Thermal electron transfer reactions between coordination compounds have been extensively investigated [1]. An electron exchange between two metal centers may not only be achieved by thermal activation but also by an optical charge transfer transition from one metal to another $[2,3,4]$. This phenomenon is well known as intervalence transfer (IT) $[2,3]$. However, it has not yet been observed to our knowledge that light-induced intervalence transfer does lead to a permanent and detectable change in the valency of the participating transition metals. Apparently fast radiationless transitions restore the thermodynamically stable oxidation states which existed prior to IT excitation. But under favorable conditions it should be possible to observe a photochemical redox reaction initiated by IT excitation of a complex containing two transition metal centers.

We have explored this possibility and have found that the irradiation of aqueous $\left[\left(\mathrm{NH}_{3}\right)_{5} \mathrm{Co}(\mathrm{III}) \mathrm{NCRu}(\mathrm{II})(\mathrm{CN})_{5}\right]^{-}$leads to a redox reaction under formation of $\mathrm{Co}^{2+}$ and $\mathrm{Ru}(\mathrm{CN})_{6}^{3-}$. We believe that this photochemical redox reaction is initiated by a direct optical electron transfer from $\mathrm{Ru}$ (II) to $\mathrm{Co}$ (III). If $\mathrm{Ru}(\mathrm{II})$ is replaced by $\mathrm{Fe}(\mathrm{II})$ the redox reaction occurs as a thermal process $[5,6]$. In our opinion these photochemical and thermal redox reactions are closely related processes which find a common explanation on the basis of a theory advanced by N. S. Hush $[3,7]$.

\section{Experimental Section}

Materials. $\left[\mathrm{Co}\left(\mathrm{NH}_{3}\right)_{5} \mathrm{H}_{2} \mathrm{O}\right]\left(\mathrm{ClO}_{4}\right)_{3}[8]$, $\left[\mathrm{Co}\left(\mathrm{NH}_{3}\right)_{6}\right] \mathrm{Cl}_{3}$ [9], and $\mathrm{K}_{4} \mathrm{Ru}(\mathrm{CN})_{6}[10]$ were prepared according to the literature.

$\mathrm{K}_{3} \mathrm{Ru}(\mathrm{CN})_{6} \cdot \mathrm{K}_{3} \mathrm{Ru}(\mathrm{CN})_{6}$ could not be isolated. A solution of $\mathrm{K}_{3} \mathrm{Ru}(\mathrm{CN})_{6}$ was prepared by oxidation of an acidic solution of $\mathrm{K}_{4} \mathrm{Ru}(\mathrm{CN})_{6}$ with $\mathrm{H}_{2} \mathrm{O}_{2}$. The spectrum of this solution shows all the characteristic absorption bands of $\mathrm{K}_{3} \mathrm{Ru}(\mathrm{CN})_{6}$ [11].

$\left[\mathrm{Co}\left(\mathrm{NH}_{3}\right)_{5} \mathrm{H}_{2} \mathrm{O}\right]_{4}\left[\mathrm{Ru}(\mathrm{CN})_{6}\right]_{3} \cdot 5 \mathrm{H}_{2} \mathrm{O}$. Equal volumes of diluted solutions of $\left[\mathrm{Co}\left(\mathrm{NH}_{3}\right)_{5} \mathrm{H}_{2} \mathrm{O}\right]\left(\mathrm{ClO}_{4}\right)_{3}$ and $\mathrm{K}_{4} \mathrm{Ru}(\mathrm{CN})_{6}$ were mixed, whereby slow precipitation of insoluble, yellow crystals of $\left[\mathrm{Co}\left(\mathrm{NH}_{3}\right)_{5} \mathrm{H}_{2} \mathrm{O}\right]_{4}\left[\mathrm{Ru}(\mathrm{CN})_{6}\right]_{3} \cdot 5 \mathrm{H}_{2} \mathrm{O}$ took place. The crystals were filtered out, washed with water, ethanol, ether, and dried under reduced pressure at room temperature. The yield was essentially quantitative. Anal. Calcd. for $\left[\mathrm{Co}\left(\mathrm{NH}_{3}\right)_{5} \mathrm{H}_{2} \mathrm{O}\right]_{4}\left[\mathrm{Ru}(\mathrm{CN})_{6}\right]_{3} \cdot 5 \mathrm{H}_{2} \mathrm{O}$; C, $14.30 ; \mathrm{N}, 34.90 ; \mathrm{H}, 5.15$; Co, 15.63. Found: C, 14.40; N, 34.67; H, 5.20; Co, 15.59 .

$\mathrm{Na}\left[\left(\mathrm{NH}_{3}\right)_{5} \mathrm{CoNCRu}(\mathrm{CN})_{5}\right] \cdot 3 \mathrm{H}_{2} \mathrm{O} \cdot\left[\mathrm{Co}\left(\mathrm{NH}_{3}\right)_{5} \mathrm{H}_{2} \mathrm{O}\right]_{4}\left[\mathrm{Ru}(\mathrm{CN})_{6}\right]_{3}$. $5 \mathrm{H}_{2} \mathrm{O}$ was heated at $60^{\circ}$ for several days, whereby its color changed from yellow to dark brown. The brown product was taken up with water. An insoluble residue was filtered out and discarded. The clear solution was percolated through a cation-exchange column. The orange solution which passed the cation-exchange column was then percolated through an anion-exchange column where it was absorbed. Upon elution with a solution of sodium chloride the orange solution was recovered and evaporated under reduced pressure until orange crystals separated. This material was collected 
by filtration and dissolved in water. Addition of ethanol yielded an orange product which was filtered out, washed with ethanol and ether. Anal. Calcd. for $\mathrm{Na}\left[\left(\mathrm{NH}_{3}\right)_{5} \mathrm{CoNCRu}(\mathrm{CN})_{5}\right] \cdot 3 \mathrm{H}_{2} \mathrm{O}$ : C, 15.0; N, 32.12; H, 4.42. Found: C, 14.91; N, 32.08; H, 5.30.

\section{Photolysis Procedure}

The light source used was a $100 \mathrm{~W}$ Osram high-pressure mercury lamp. A Schott interference filter 366 limited the ultraviolet radiation emitted to the wavelength of the mercury line at $366 \mathrm{~nm}$. Alternatively, the filter combination of the interference filters Balzer $\mathrm{K} 3$ plus Balzer K 4 transmitted light between 520 and $560 \mathrm{~nm}$.

The photolysis were carried out at room temperature in a $5-\mathrm{cm}$ cylindrical spectrophotometer cell, using concentrations of complex such as to have essentially complete light absorption (about $3 \cdot 10^{-3} \mathrm{M}$ for irradiations in the uv region and $10^{-2} \mathrm{M}$ for those in the visible region). An aliquot of the solution to be analysed was kept in the dark, at the same temperature, so that any thermal reaction could be noted and allowed for. However, the rate constant for the thermal reaction is very small, and since irradiation times did not exceed 40 minutes, correction for the thermal reaction was negligible. The total amount of photolysis was limited to about $10 \%$ to avoid possible secondary photochemical reactions. Absorbed light intensities were determined by Ferrioxalate actinometry [12] or by Reineckate actinometry [13] in the visible region.

\section{Analytical Procedure}

Cobaltous ion was determined by forming the blue complex ion, $\mathrm{Co}(\mathrm{NCS})_{4}^{2-}$ in a water-acetone solution and measuring the absorbance $\left(\varepsilon=1.7 \cdot 10^{3}\right.$ at $\left.625 \mathrm{~nm}\right)$, according to a procedure taken from the literature [14].

\section{Measurements}

Infrared spectra were measured with a Perkin Elmer 325 IR spectrophotometer. Samples were bromide pellets. Visible and ultraviolet spectra were measured in $1-\mathrm{cm}$ cells with a Cary 14 recording spectrophotometer and a Zeiss PMQ II spectrophotometer for measurements at selected wavelengths.

\section{Results and Discussion}

The complex ion $\left[\left(\mathrm{NH}_{3}\right)_{5} \mathrm{Co}(\mathrm{III}) \mathrm{NCRu}(\mathrm{II})(\mathrm{CN})_{5}\right]^{-}$was prepared in analogy to the synthesis of $\left[\left(\mathrm{NH}_{3}\right)_{5} \mathrm{Co}\right.$ (III)NC. - $\left.\mathrm{Co}(\mathrm{III})(\mathrm{CN})_{5}\right]$ [15]. The existence of a CoNCRu bridge was confirmed by IR spectroscopy. The compound $\left[\mathrm{Co}\left(\mathrm{NH}_{3}\right)_{5}\right.$. $\left.\cdot \mathrm{H}_{2} \mathrm{O}\right]_{4}\left[\mathrm{Ru}(\mathrm{CN})_{6}\right]_{3} \cdot 5 \mathrm{H}_{2} \mathrm{O}$, which was obtained in the first step of the synthesis, shows essentially the same absorption spectrum as $\mathrm{K}_{4}\left[\mathrm{Ru}(\mathrm{CN})_{6}\right]$ in the region of the cyanide stretching vibrations. The absorption maximum of both compounds, which shows some structure, appears at $2050 \mathrm{~cm}^{-1}$. However, the final product $\mathrm{Na}\left[\left(\mathrm{NH}_{3}\right)_{5} \mathrm{CoNCRu}(\mathrm{CN})_{5}\right]$. $3 \mathrm{H}_{2} \mathrm{O}$ exhibits a well separated additional band $\left(2135 \mathrm{~cm}^{-1}\right)$ at higher wavenumbers which is characteristic of bridging cyanide [16].

The electronic structure of a binuclear complex is influenced by the interaction of both metal centers $[3,4]$. If the interaction is weak the electronic structure can be described as the sum of the electronic structures of two mononuclear complexes which constitute the binuclear complex. For example, the absorption spectrum of $\left[\left(\mathrm{NH}_{3}\right)_{5} \mathrm{Co}(\mathrm{III}) \mathrm{NC}\right.$. - $\left.\mathrm{Co}(\mathrm{III})(\mathrm{CN})_{5}\right]$ [15] consists of the superimposed spectra of $\mathrm{Co}\left(\mathrm{NH}_{3}\right)_{6}^{3+}$ (the ligand field strength of cyanide coordinated via nitrogen is about the same as that of ammonia) $[15,17,18]$ and $\mathrm{Co}(\mathrm{CN})_{6}^{3-}$. Similarly, the spectrum of $\left[\left(\mathrm{NH}_{3}\right)_{5} \mathrm{Co}(\mathrm{III})\right.$. $\left.\mathrm{CNCo}(\mathrm{III})(\mathrm{CN})_{5}\right][17]$, which is a linkage isomer of $\left[\left(\mathrm{NH}_{3}\right)_{5}\right.$.
$\left.\mathrm{CoNCCo}(\mathrm{CN})_{5}\right]$, has been shown to be a superimposition of the spectra of $\mathrm{Co}\left(\mathrm{NH}_{3}\right)_{5} \mathrm{CN}^{2+}$ and $\mathrm{Co}(\mathrm{CN})_{5} \mathrm{NH}_{3}^{2-}$. The IR spectra of these binuclear complexes are also largely identical with those of the mononuclear components with the exception of the additional bands caused by the bridging cyanide. However, an important consequence of the weak interaction of both metal centers is the possibility of the occurance of electronic transitions between both metals which give rise to additional absorption bands in the electronic spectrum $[2,3,4]$. Since such a transition leads to the reduction of one metal and oxidation of the other one this charge transfer has been termed intervalence transfer (IT) $[2,3]$. In the case of the binuclear complexes mentioned above an IT band does not occur in the experimentally accessible region probably because the energy of any of the possible transitions from $\mathrm{Co}(\mathrm{III}) / \mathrm{Co}$ (III) to $\mathrm{Co}(\mathrm{II}) / \mathrm{Co}(\mathrm{IV})$ is very high. However, the complex ions $\left[\left(\mathrm{NH}_{3}\right)_{5} \mathrm{Ru}(\mathrm{II})\right.$ pyrazine $\mathrm{Ru}(\mathrm{III})$. $\left.\cdot\left(\mathrm{NH}_{3}\right)_{5}\right]^{5+}[19]$ and $\left[(\mathrm{NC})_{5} \mathrm{Fe}(\mathrm{II}) \mathrm{CNFe}(\mathrm{III})(\mathrm{CN})_{5}\right]^{6-}[20]$ exhibit IT bands even in the near infrared since the electron exchange does not require much energy. In analogy to these examples the ion $\left[\left(\mathrm{NH}_{3}\right)_{5} \mathrm{Co}(\mathrm{III}) \mathrm{NCRu}(\mathrm{II})(\mathrm{CN})_{5}\right]^{-}$may also be expected to contain weakly interacting metal centers. This assumption is supported by the IR spectrum of the binuclear complex which is essentially identical with those of the constituting mononuclear complexes, again with the exception of the additional band caused by the bridging cyanide. Since also the electronic spectrum should be composed of the spectra of both components the binuclear complex should exhibit only the ligand field bands of $\mathrm{Co}\left(\mathrm{NH}_{3}\right)_{6}^{3+}$ above $300 \mathrm{~nm}$ (Fig. 1) because $\mathrm{Ru}(\mathrm{CN})_{6}^{4-}$ does not absorb above $300 \mathrm{~nm}[11,21]$. However, only the first ligand field band of $\mathrm{Co}\left(\mathrm{NH}_{3}\right)_{6}^{3+}$ at $475 \mathrm{~nm}$ is clearly identified in the spectrum of the binuclear complex (Fig. 1). The second ligand field band of $\mathrm{Co}\left(\mathrm{NH}_{3}\right)_{6}^{3+}$ at $340 \mathrm{~nm}$ is hidden under another more intense band at $375 \mathrm{~nm}$. In our opinion this new absorption, which does not have a counterpart in both mononuclear complexes, belongs to an IT transition from $\mathrm{Ru}(\mathrm{II})$ to $\mathrm{Co}(\mathrm{III})$ which is the energetically most probable redox process between $\mathrm{Ru}(\mathrm{II})$ and $\mathrm{Co}(\mathrm{III})$. This assignment is also supported by the photochemical redox reaction of $\left[\left(\mathrm{NH}_{3}\right)_{5} \mathrm{Co}(\mathrm{III}) \mathrm{NCRu}(\mathrm{II})(\mathrm{CN})_{5}\right]^{-}$which will be discussed below. Only recently an absorption band in the spectrum of $\left.[\text { (histidinato })_{2} \mathrm{Co}(\mathrm{III}) \mathrm{NCFe}(\mathrm{II}) \cdot(\mathrm{CN})_{5}\right]^{3-}$ near $500 \mathrm{~nm}$ was assigned to an IT [Fe(II) to $\mathrm{Co}(\mathrm{III})]$ transition [22].

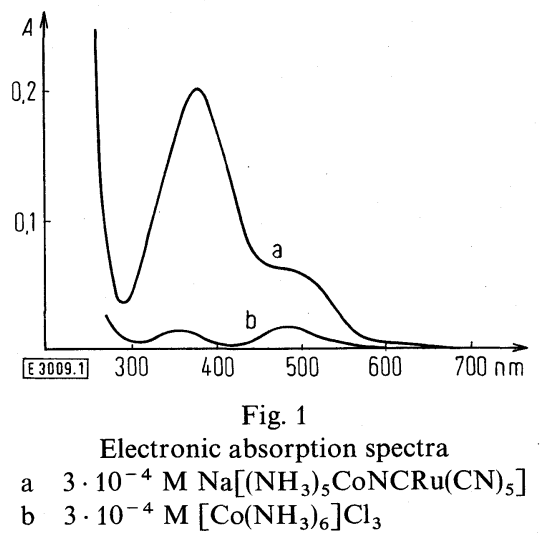




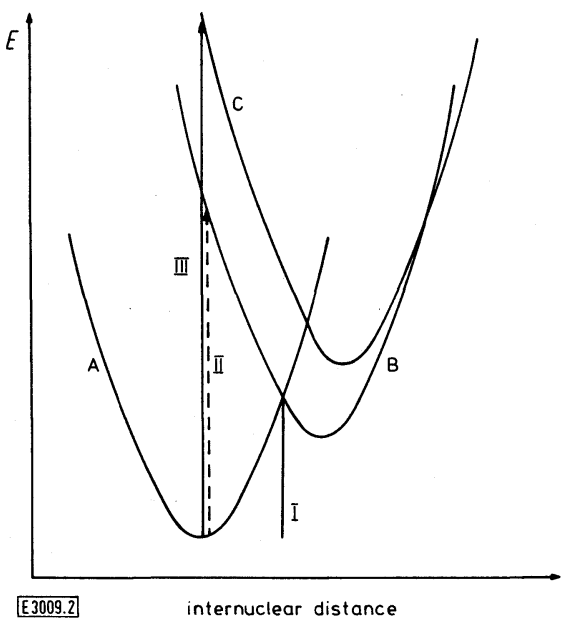

Fig. 2

Potential curve diagram of electronic IT states of $\left[\left(\mathrm{NH}_{3}\right)_{5} \mathrm{CoNCRu}(\mathrm{CN})_{5}\right]$

A $\mathrm{Co}(\mathrm{III}) \mathbf{t}_{2 \mathrm{~g}}^{6}, \mathrm{Ru}(\mathrm{II}) \mathbf{t}_{2 \mathrm{~g}}^{6}$;

B $\quad \operatorname{Co}($ II $) t_{2 g}^{5} \mathrm{e}_{\mathrm{g}}^{2}, \mathrm{Ru}(\mathrm{III}) \mathrm{t}_{2 \mathrm{~g}}^{5}$;

C $\quad \mathrm{Co}(\mathrm{II}) \mathrm{t}_{2 \mathrm{~g}}^{6} \mathrm{e}_{\mathrm{g}}^{1}, \mathrm{Ru}(\mathrm{III}) \mathrm{t}_{2 \mathrm{~g}}^{5}$

I thermal activation energy

II spin forbidden IT transition

III observed IT transition

A qualitative potential curve diagram (Fig. 2) which is based on a theoretical model $[3,7]$ gives a more detailed picture of the intervalence interaction. The left-hand curve represents the electronic ground state of $\left[\left(\mathrm{NH}_{3}\right)_{5} \mathrm{Co}(\mathrm{HI}) \mathrm{NC}\right.$. $\left.\cdot \mathrm{Ru}(\mathrm{II})(\mathrm{CN})_{5}\right]^{-}$. The lower curve on the right side represents the ground state after the electron has been transfered from $\mathrm{Ru}(\mathrm{II})\left(\mathrm{t}_{2 \mathrm{~g}}^{6}\right)$ to $\mathrm{Co}(\mathrm{III})\left(\mathrm{t}_{2 \mathrm{~g}}^{6}\right)$. The new ground state configuration should contain $\mathrm{Ru}$ (III) ( $\left.\mathrm{t}_{2 \mathrm{~g}}^{5}\right)$ and high spin $\mathrm{Co}(\mathrm{II})\left(\mathrm{t}_{2 \mathrm{~g}}^{5} \mathrm{e}_{\mathrm{g}}^{2}\right)$ as expected for octahedral $\mathrm{Co}$ (II) complex ammines. The upper curve on the right side represents the lowest excited state of $\left[\left(\mathrm{NH}_{3}\right)_{5} \mathrm{Co}(\mathrm{II}) \mathrm{NCRu}(\mathrm{III})(\mathrm{CN})_{5}\right]^{-}$with $\mathrm{Co}(\mathrm{II})$ in the low spin configuration $\mathrm{t}_{2 \mathrm{~g}}^{6} \mathrm{e}_{\mathrm{g}}^{1}$. This curve may be displaced further to the right due to strong Jahn-Teller distortion of low spin octahedral $\mathrm{Co}$ (II) complexes [23]. There are two optical IT transitions possible. However, one of them (II in Fig. 2) is spin forbidden and may not be seen in the spectrum. The second one (III in Fig. 2) is spin allowed and assigned to the observed absorption band of $\left[\left(\mathrm{NH}_{3}\right)_{5} \mathrm{Co}(\mathrm{III}) \mathrm{NCRu}(\mathrm{II})(\mathrm{CN})_{5}\right]^{-}$ at $375 \mathrm{~nm}$. The intensity of this band $(\varepsilon=690)$ is much higher than that of a LF band but rather low for a CT transition. However this is not too surprising since the corresponding electronic transition is of type "te" (from $\mathrm{Ru}$ (II) $\mathrm{t}_{2 \mathrm{~g}}$ to $\mathrm{Co}$ (III) $\mathrm{e}_{\mathrm{g}}$ ) and hence not allowed [24].

Upon irradiation into the IT band $\left[\left(\mathrm{NH}_{3}\right)_{5} \mathrm{Co}(\mathrm{III}) \mathrm{NC}\right.$. $\left.\cdot \mathrm{Ru}(\mathrm{II})(\mathrm{CN})_{5}\right]^{-}$, dissolved in water, underwent a redox reaction under formation of $\mathrm{Ru}(\mathrm{CN})_{6}^{3-}$ (Fig. 3), ammonia and $\mathrm{Co}^{2+}$ with a quantum yield $\phi=0.46$. Neither $\mathrm{Co}\left(\mathrm{NH}_{3}\right)_{6}^{3+}$ nor $\mathrm{Ru}(\mathrm{CN})_{6}^{4-}$ is photosensitive in this wavelength region. The irradiation of the binuclear complex into the ligand field band led also to this redox reaction but with a much smaller quantum yield $\phi=0.12$. This observation is probably due to the overlap of the long wavelength tail of the IT band with the ligand field band (Fig. 1).

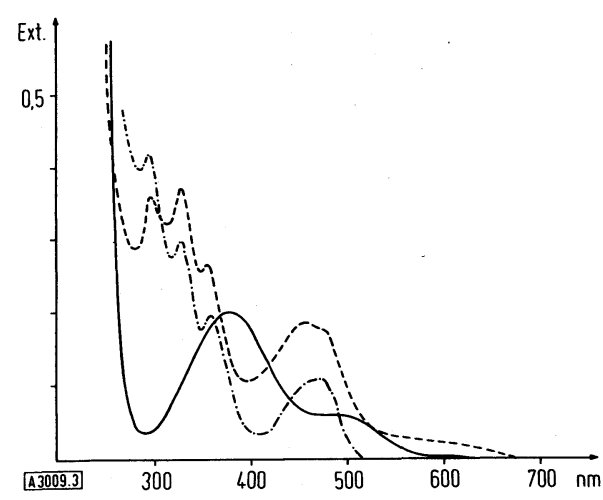

Fig. 3

Absorption spectra:

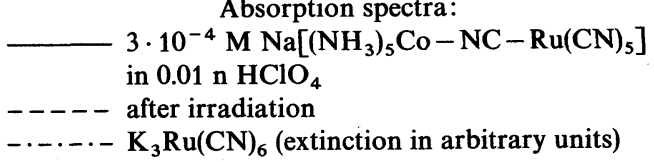

According to the potential curve diagram the IT transition (III in Fig. 2) leads to an intervalence transfer excited state which initiates the redox reaction. This photoredox reaction is simply a special case of the photochemistry of aqueous $\mathrm{Co}$ (III) complex ammines which generally undergo redox reactions under formation of $\mathrm{Co}^{2+}$ and oxidized ligands upon irradiation into ligand to Co(III) charge transfer bands $[25,26]$. The binuclear complex may thus be regarded as an octahedral $\mathrm{Co}(\mathrm{III})$ pentaammine complex with $\mathrm{Ru}(\mathrm{CN})_{6}^{4-}$ as the sixth ligand. Also $\mathrm{Ru}(\mathrm{CN})_{6}^{4-}$ is photosensitive itself. Upon irradiation at $254 \mathrm{~nm}$ into the metal to ligand charge transfer band of aqueous $\mathrm{Ru}(\mathrm{CN})_{6}^{4-}$ the production of photoelectrons has been observed [27]. Hence it is not surprising that the interaction of $\mathrm{Co}$ (III) and $\mathrm{Ru}$ (II) in the binuclear complex creates a new low lying CT state which upon excitation leads to the observed photoredox reaction.

According to the theory optical IT transitions and thermal redox reactions are closely related processes $[3,7]$. A thermal redox reaction is then simply a radiationless transition. It may occur if the thermal energy of the system is high enough to overcome the activation energy. In the case of $\left[\left(\mathrm{NH}_{3}\right)_{5}\right.$. . $\left.\mathrm{Co}(\mathrm{III}) \mathrm{NCRu}(\mathrm{II})(\mathrm{CN})_{5}\right]^{-}$the activation energy (I in Fig. 2) is apparently rather high since the binuclear complex is stable at least at room temperature. However, the attempt to prepare $\left[\left(\mathrm{NH}_{3}\right)_{5} \mathrm{Co}(\mathrm{III}) \mathrm{NCFe}(\mathrm{II})(\mathrm{CN})_{5}\right]^{-}$failed [6], since the ion pair $\mathrm{Co}\left(\mathrm{NH}_{3}\right)_{5} \mathrm{H}_{2} \mathrm{O}^{3+} / \mathrm{Fe}(\mathrm{CN})_{6}^{4-}$ undergoes a thermal redox reaction under formation of $\mathrm{Co}^{2+}$ and $\mathrm{Fe}(\mathrm{CN})_{6}^{3-}$ $[5,6]$. This reaction has been classified as outer sphere redox reaction of the ion pair mentioned above [5]. However, the kinetic data are also consistent with an inner sphere mechanism if the formation of the binuclear complex is the rate determining step. Inner sphere redox reactions mediated by cyanide bridges are quite common [22, 28-34]. But irrespective of the intimate mechanism the potential curves on the right side (Fig. 2) will be lowered if $\mathrm{Ru}$ (II) is replaced by $\mathrm{Fe}(\mathrm{II})$ since $\mathrm{Fe}(\mathrm{CN})_{6}^{3-}$ is a much weaker oxidant than $\mathrm{Ru}(\mathrm{CN})_{6}^{3-}[11]$. As a consequence the thermal activation energy ( $I$ in Fig. 2) should be lowered too. This thermal redox reaction may be 
expected to be rather slow because it is initiated by a spin forbidden transition. However, it has been shown recently that radiationless transitions even if they are strongly spin forbidden can be very fast compared to the rates of chemical redox reactions [35].

\section{Acknowledgment}

Support for this research by the Deutsche Forschungsgemeinschaft and the Fonds der chemischen Industrie is gratefully acknowledged.

\section{References}

[1] For recent reviews see a) R. G. Linck, MTP International Review of Science, Inorganic Chemistry, Vol. 9, Ser. 1, M. L. Tobe, Ed., University Park Press, Baltimore, Md., 1971, p. 303 ; b) A. G. Sykes, Advan. Inorg. Chem. Radiochem. 10, $153(1967)$; c) H. Taube, Electron Transfer Reactions of Complex Ions in Solution, Academic Press, New York, N.Y., 1970.

[2] G. C. Allen and N. S. Hush, Progr. Inorg. Chem. 8, 357 (1967).

[3] N. S. Hush, Progr. Inorg. Chem. 8, 391 (1967).

[4] M. B. Robin and P. Day, Advan. Inorg. Chem. Radiochem 10, 247 (1967).

[5] D. Gaswick and A. Haim, J. Amer. chem. Soc. 93, 7347 (1971).

[6] H. Kunkely, unpublished results.

[7] N. S. Hush, Electrochim. Acta 13, 1005 (1968).

[8] E. Lenz and R. K. Murmann, Inorg. Syntheses 12, 214 (1970).

[9] J. Bjerrum and J. P. McReynolds, Inorg. Syntheses 2, 216 (1946).

[10] J. L. Howe, J. Amer. chem. Soc. 18, 981 (1896).

[11] D. D. DeFord and A. W. Davidson, J. Amer. chem. Soc. 73, 1469 (1951).

[12] C. G. Hatchard and C. A. Parker, Proc. Roy. Soc., Ser. A, 235, 518 (1956).

[13] E. E. Wegner and A. W. Adamson, J. Amer. chem. Soc. 88, 394 (1966).

[14] R. E. Kitson, Analyt. Chem. 22, 664 (1950).
[15] R. A. De Castello, C. Piriz Mac-Coll, N. B. Egen, and A. Haim, Inorg. Chem. 8, 699 (1969).

[16] D. A. Dows, A. Haim, and W. K. Wilmarth, J. Inorg. Nucl. Chem. 21, 33 (1961)

[17] R. A. De Castello, C. Piriz Mac-Coll, and A. Haim, Inorg. Chem. 10, 203 (1971).

[18] D. F. Shriver, S. A. Shriver, and S. E. Anderson, Inorg. Chem. 4, 725 (1965).

[19] C. Creutz and H. Taube, J. Amer. chem. Soc. 95, 1086 (1973).

[20] R. Glauser, U. Hauser, F. Herren, A. Ludi, P. Roder, E. Schmidt, H. Siegenthaler, and F. Wenk, J. Amer. chem. Soc. 95, 8457 (1973).

[21] M. B. Robin, Inorg. Chem. 1, 337 (1962).

[22] S. Bagger and K. Gibson, Acta chem. scand. 27, 3227 (1973).

[23] M. D. Glick, J. M. Kuszaj, and J. F. Endicott, J. Amer. chem. Soc. 95, 5097 (1973).

[24] P. S. Braterman, J. chem. Soc. (A), 1471 (1966).

[25] A. Vogler and A. W. Adamson, J. physic. Chem. 74, 67 (1970).

[26] V. Balzani and V. Carassiti, Photochemistry of Coordination Compounds, Academic Press, New York, N.Y., 1970.

[27] W. L. Waltz and A. W. Adamson, J. physic. Chem. 73, 4250 (1969).

[28] A. Haim and W. K. Wilmarth, J. Amer. chem. Soc. 83, 509 (1961).

[29] A. W. Adamson and E. Gonick, Inorg. Chem. 2, 129 (1963).

[30] J. L. Burmeister and D. Sutherland, Chem. Commun. 175 (1965).

[31] J. Halpern and S. Nakamura, J. Amer. chem. Soc. 87, 3002 (1965).

[32] J. H. Espenson and J. P. Birk, J. Amer. chem. Soc. 87, 3280 (1965); 90, 1153 (1968).

[33] D. H. Huchital and R. G. Wilkins, Inorg. Chem. 6, 1022 (1967).

[34] J. P. Birk and J. Halpern, J. Amer. chem. Soc. 90, 305 (1968).

[35] J. K. Beattie, N. Sutin, D. H. Turner, and G. W. Flynn, J. Amer. chem. Soc. 95, 2052 (1973).

(Eingegangen am 20. August 1974) 